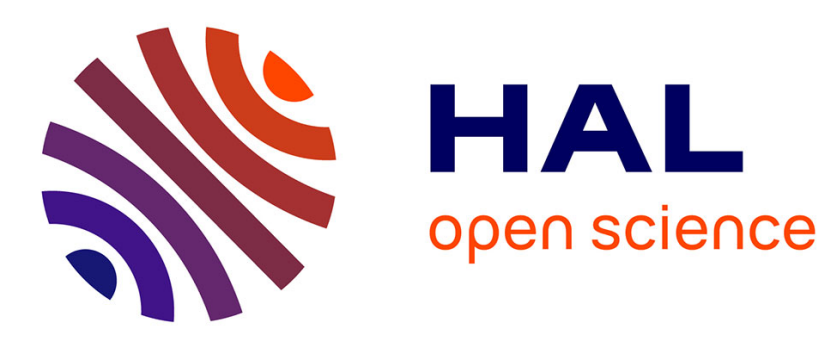

\title{
Using Rock-Eval 6 pyrolysis for tracking fossil organic carbon in modern environments: implications for the roles of erosion and weathering.
}

Yoann Copard, Christian Di Giovanni, Thomas Martaud, Patrick Albéric, Jean-Emmanuel Olivier

\section{To cite this version:}

Yoann Copard, Christian Di Giovanni, Thomas Martaud, Patrick Albéric, Jean-Emmanuel Olivier. Using Rock-Eval 6 pyrolysis for tracking fossil organic carbon in modern environments: implications for the roles of erosion and weathering.. Earth Surface Processes and Landforms, 2006, 31, №2 (2), pp.135 - 153. 10.1002/esp.1319 . hal-00022590

\section{HAL Id: hal-00022590 \\ https://hal-insu.archives-ouvertes.fr/hal-00022590}

Submitted on 4 Jan 2007

HAL is a multi-disciplinary open access archive for the deposit and dissemination of scientific research documents, whether they are published or not. The documents may come from teaching and research institutions in France or abroad, or from public or private research centers.
L'archive ouverte pluridisciplinaire HAL, est destinée au dépôt et à la diffusion de documents scientifiques de niveau recherche, publiés ou non, émanant des établissements d'enseignement et de recherche français ou étrangers, des laboratoires publics ou privés. 


\title{
USING ROCK-EVAL 6 PYROLYSIS FOR TRACKING FOSSIL ORGANIC CARBON IN MODERN ENVIRONMENTS: IMPLICATIONS FOR THE ROLES OF EROSION AND WEATHERING
}

\author{
YOANN COPARD $^{1 *}$, CHRISTIAN DI-GIOVANNI ${ }^{2}$, THOMAS MARTAUD ${ }^{2}$, PATRICK $^{*}$ \\ ALBERIC $^{2}$, JEAN-EMMANUEL OLIVIER ${ }^{3}$ \\ ${ }^{1}$,UMR INRA CARRTEL, CISM, Université de Savoie, Technolac, 73376 Le Bourget du Lac cedex, France \\ ${ }^{2}$ ISTO, UMR 6113 du CNRS, Bat. Geosciences, rue de St Amand BP 675945067 Orléans cedex 2, France \\ ${ }^{3}$ CEMAGREF, Grenoble, Unité de recherche ETNA, BP 76, 38402 Saint Martin d'Hères, France
}

"Correspondance to: Y. Copard, UMR INRA CARRTEL, Domaine universitaire Technolac, 73376 Le Bourget du Lac cedex, France. E-mail: yoann.copard@univ-savoie.fr. Fax: (33) 04-79-75-88-80

\begin{abstract}
This work deals with the debate on the Fossil Organic Carbon (FOC) input in modern environments, its possible implication for the carbon cycle and suggests the use of Rock-Eval 6 pyrolysis as a relevant tool for tracking FOC in such environments. Considering that such a delivery is mainly due to supergene processes affecting continental surface, we studied OM in different OM reservoirs such as bedrocks, alterites, soils and rivers in two experimental catchments (Draix, Alpes de Haute Provence, France). Samples, collected in these different compartments, were subjected to geochemical (Rock-Eval 6 pyrolysis) investigations and artificial bacterial degradations. After comparison of geochemical fingerprint of samples, some geochemical markers of FOC were defined and tracked in the different reservoirs. Our results confirm the contribution of Fossil Organic Carbon (FOC) in modern soils and rivers and display the various influences of the weathering and erosional processes on the fate of FOC during its exchange between these pools. In addition, the contrasted behaviour of these markers upon these supergene processes has also pointed out the refractory or labile characters of the FOM. Bedrock to river fluxes, controlled by gully erosion, are characterised by a qualitative and quantitative preservation of FOM. Bedrock to alterite fluxes, governed by chemical weathering, are characterised by a FOC mineralisation without qualitative changes in deeper alterites. Alterite to soils fluxes, ruled by (bio)chemical weathering are characterised by a strong FOC mineralisation and qualitative changes of FOM. Henceforth, weathering and erosional processes induce different FOM evolution and affect the fate of FOC toward the global carbon cycle. In this study, gully erosion would involve a maintaining of an ancient sink for the global carbon cycle, while (bio)chemical processes rather a source of $\mathrm{CO}_{2}$. Finally, this study suggests that Rock-Eval 6 pyrolysis would be considered as a relevant tool for tracking FOC in modern environment.
\end{abstract}

Keywords: Fossil organic matter, experimental watersheds, marls, alterites, soils, riverine particles, mechanical erosion, chemical weathering, biochemical weathering, carbon cycle, RE6 pyrolysis.

\section{INTRODUCTION}

The current increase of atmospheric $\mathrm{CO}_{2}$ since the Industrial Revolution, considered as a green house gas, induces a series of climatic, environmental, and human consequences (Prentice et al., 2001). This atmospheric $\mathrm{CO}_{2}$ concentration is regulated by processes controlling the carbon fluxes between different carbon pools such as atmosphere, ocean, continental hydrosphere, soil, biomass, and lithosphere (Houghton, 2003). Nevertheless, the present debate concerning the unidentified nature of the missing carbon sinks (Kaufmann and Stock, 2003) gives us evidence that many unknowns punctuate the estimation of these fluxes. As an example until to now, numerous estimations of soil or river carbon amounts or fluxes have been calculated (Eswaran et al., 1993; Balesdent, 1996; Batjes, 1996; Adams and Faure, 
1996; Carter et al., 1997; Holland, 1978; Berner et al., 1983; Degens et al., 1991; Probst, 1992; Amiotte Suchet; 1995; Ludwig et al., 1996; Aitkenhead and McDowell, 2000), and all these estimations rely on the prerequisite that the OC occurring in soils or loaded in rivers exclusively originate from the current biomass. Such estimates do not take into account FOC yielded by weathering and erosion of sedimentary rocks that can supply soils, rivers and atmosphere. For instance, Meybeck (1993) and Blair et al. (2003) suggest that FOC could reflect up to $40-45 \%$ of Particulate OC (POC) annually carried by rivers to world oceans. Hence, this supply would represent a significant flux (between 0.04-0.08 Gt FOC. $\mathrm{y}^{-1}$ ) of C for the global carbon cycle (Table 1). These different hypothesis or considerations point out the problem of the validity of the quantification of carbon stocks and fluxes.

FOC delivery in soils or rivers is mainly controlled by weathering and erosion affecting continental surfaces composed of shales carbonates sands and sandstones. At a global scale, the chemical weathering of shales and carbonates, that represent about $40-45 \%$ of continental surface (Meybeck, 1987: Amiotte-Suchet et al., 2003) annually releases $0.1 \mathrm{Gt}$ of FOC (Di-Giovanni et al., 2002). Although their chemical weathering rates are lower than shales and carbonates (Amiotte-Suchet, 1995), those delivered from sands and sandstones remain unknown. In addition, no FOC fluxes from the mechanical erosion of outcropping sedimentary rocks have been reported. However, at global scale, mechanical rock denudation is 4 to 11 higher than those due to chemical one (Probst, 1992; Gaillardet, pers. com.).

Nevertheless, a meaningful part of the delivered FOC can be mineralised as describe some investigations (Petsch et al., 2000) studying the organic content of weathering profiles (alterite). Following a complementary way, another recent works promote the occurrence of FOM or FOC both in modern soils and rivers (Di-Giovanni et al., 1999a; 1999b; Bilodeau et al., 1990; Raymond and Bauer, 2001) and would mean that a part of FOC is not mineralised during these supergene processes. These works only complete other older observations, made by organic petrographs or palynologists that have also testified occurrence of FOM in marine sediments (Gadel and Ragot, 1973; Combaz, 1980) or in riverine particles (Johnson and Thomas, 1884). These different points should drive future research toward 1) the evaluation of delivery processes (chemical and mechanical) of FOC in supergene pools, 2) the appreciation of parameters involved in its mineralisation and 3) the assessment of its real and significant contribution to the global carbon cycle.

This paper focuses on two main goals. The first is to consider this work as preliminary pointing up the contributions of the gully erosion and (bio)chemical weathering to the delivery and fate of FOC in modern environment. With this respect, FOC was tracked following a multi carbon pool approach (bedrocks, alterites, soils and rivers) from two experimental watersheds (Draix, Alpes de Haute Provence, France). Choice of these two field sites lies in the fact that they are monitored by the Cemagref and their geomorphology, vegetal cover, soils, geology and sediment products are well described (Brochot and Meunier, 1995). The second objective is to suggest that the Rock-Eval 6 pyrolysis (Vinci Technologies ${ }^{\circledR}$ ), widely used by petroleum engineers for the geochemical analyses of $\mathrm{OM}$ in sedimentary rocks (Lafargue et al., 1998), can be also an attractive tool for tracking FOC in modern environment. This tracking is based on the identification of specific geochemical fossil markers in marly rocks (supposed to contain a significant FOC content). Without any heavy procedures prior to RE6 pyrolysis, this method rapidly provides both qualitative and quantitative fingerprints of the organic matter and was successfully tested for recent organic materials (Di-Giovanni et al., 1998 ; Noël, 2001 ; Disnar et al., 2003).

RESEARCH SITE AND SAMPLING STRATEGY 


\section{Experimental catchments}

Studied area consists in two small experimental watersheds (Le Laval and Le Brusquet) located near Digne (Alpes-de-Haute-Provence, France, Figure 1a). Their physical characteristics are listed in the table 2 .

Le Laval watershed is characterised by a poor vegetation density $(21 \%)$ composed with grass, graminaceous, broom, scots pines and oaks. Callovo-oxfordian to middle Bathonian marly limestones characterise its bedrock. Le Brusquet watershed is covered at $87 \%$ by a scots pines forest. Bedrock is composed of Toarcian black shales, upper Aalenian grey shales, lower Aalenian limestones and Bajocian marly limestone. All these geological formations develop badlands facies due to strong gully erosion rates (Brochot and Meunier, 1995).

\section{Samples}

Samples were collected into various supergene carbon reservoirs, which can contain some FOC. These are alterite, soils, fluvial particles and bedrocks.

Five bedrocks, representing the whole geological facies observed in these watersheds, were examined (Figure 1b, c). Only Callovo-oxfordian substratum from Le Laval was analysed while the whole geological formation of Le Brusquet, from Upper Toarcian to Bajocian (Haccard et al., 1989), were sampled (Figure 1b).

In Le Laval watershed, one alteration profile ALA1 was collected in a flat area. Callovooxfordian marls constitute its bedrock and it is overlaid by a meadow (Figure 1c).

Because, soils characteristics are mainly rely to vegetation and bedrock ones (Duchauffour, 2001), five soil profiles were also collected according variation of these two parameters. As soon as this was feasible, we have separated humus into OL, OF and $\mathrm{OH}$ horizons and sampled Al organo-mineral horizon (Figure 1b, c).

Height riverine particles, from the two watersheds and collected at different seasons at the outlets of the watersheds, were also studied. They consist into five suspended loads (SL), picked up with automatic sampling, and three bed loads (BL). Four SL originate from Le Laval and correspond to spring (2 samples), summer and autumn whereas only a summery SL was examined for Le Brusquet. Two BL were sampled in spring and summer and autumnal BL for Le Brusquet.

\section{METHODS}

\section{Rock-Eval pyrolysis}

RE6 pyrolysis comprises two successive analytical stages performed with a temperature program of $25^{\circ} \mathrm{C} \mathrm{min}^{-1}$. The first one consists, in a pyrolysis of $100 \mathrm{mg}$ of sample, previously crushed, in oven. Pyrolysis effluents are carried by nitrogen and hydrocarbons and oxygenate compounds yielded during a temperature range of $200-650^{\circ} \mathrm{C}$ are quantified. The second consists in the oxidation, in an oven and upon air, of the pyrolysed carbonaceous residue subjected to a temperature comprised between $400^{\circ} \mathrm{C}$ and $750^{\circ} \mathrm{C}$ (Espitalié et al., 1985; Lafargue et al., 1998; Figure 2).

Here, we focus on $S_{2}$ signal delivered by pyrolysis stage and whose intensity depends of the amount of hydrocarbon compounds progressively released during thermal cracking of the sample. Analysis of this signal provides some parameters such as i) $T_{\text {peak }}$, expressed in ${ }^{\circ} \mathrm{C}$, that is the temperature at which the release the maximal amount of hydrocarbon occurs (temperature at the top of the signal) and ii) Hydrogen Index (HI, in mg $\mathrm{HC} \mathrm{g}^{-1} \mathrm{TOC}$ ), that is 
can defined as an indicator of the richness of hydrogen of pyrolysed sample. Amount of Organic Carbon (OC) of samples is given by Total Organic Carbon (TOC, expressed in \%), that is equal to the sum of pyrolysed organic carbon plus residual organic carbon provided by oxidation stage (Figure 2).

\section{Deconvolution of $S_{2}$ signals from RE6 pyrolysis}

$\mathrm{S}_{2}$ peaks are frequently accompanied with shoulders - e.g. multilobed signals - defined as the successive release of various hydrocarbon compounds displaying different thermal stabilities (Copard, 2002; Disnar et al., 2003). Deconvoluting the $\mathrm{S}_{2}$ signal requires computer treatments as those developed by Peakfit software $\left(\right.$ SPSS $\left.^{\circledR}\right)$ and proceeding by an automatic iteration which should reproduce the best adjustment of the $S_{2}$ signal (i.e. $r^{2}$ determination coefficient close to 1). This treatment provides different elemental gaussians describing the release of hydrocarbon compounds, whose their common characteristic feature is to be emitted in a close temperature range. Thereby, such compounds can be belonged to a single cluster.

Although totally arbitrary, the best adjustment of deconvolution of the studied samples is obtained with a model with 6 gaussians sharing the hydrocarbon compounds into 6 clusters. The maximal amount of hydrocarbon compounds of each cluster is defined by its own Tpeak, or rather by a close range of Tpeak $\left( \pm 15^{\circ} \mathrm{C}\right)$ whose mean temperature is: $250^{\circ} \mathrm{C}, 310^{\circ} \mathrm{C}$, $370^{\circ} \mathrm{C}, 435^{\circ} \mathrm{C}, 480^{\circ} \mathrm{C}$ and $550^{\circ} \mathrm{C}$ and respectively named $\mathrm{F} 1, \mathrm{~F} 2, \mathrm{~F} 3, \mathrm{~F} 4, \mathrm{~F} 5$ and $\mathrm{F} 6$. Later, the relative contribution of these clusters, to the $S_{2}$ signal was also semi-quantified by the calculation of peak surfaces of the corresponding gaussians plotted to those of the entire $S_{2}$ signal surface (Figure 3-4, Table 3).

\section{Biochemical Oxygen Demand (BOD)}

Despite this method is widely used in term of environmental indicator in wastewater treatment processes, and notably for monitoring the degree of pollution due to biodegradable compounds in aquatic environment (Hikuma and Yashuda, 1988), BOD is, at our knowledge, unperformed for the simulation of the bacterial degradation of FOC in soils. Although the bacterial community is different from those residing in soils, BOD is here performed in order to simulate the biodegradation occurring in such environment and attributable to the bacterial community (Lin, 1988 ; Albéric, 1998).

Experiments, providing signals from aerobic conditions, were performed in an incubator vial $(510 \mathrm{ml}) \mathrm{kept}$ in the darkness, in close system, with water $(432 \mathrm{ml})$ and air, and at constant temperature $\left(20^{\circ} \mathrm{C}\right)$. Because these simulations were carried out both at constant temperature and volume, measurements of the variation of gas amount can be estimated by the variation of pressure (Heddle and Tavener, 1981). Hence, oxygen uptake can be calculated with the $\mathrm{CO}_{2}$ absorption released during aerobic bacterial respiration in three sodium hydroxide chips incorporated into incubators. 100 to $150 \mathrm{mg}$ of substrates plus two nutrients capsules and 100 $\mu 1$ of bacterial seed (Bacta-pur ${ }^{\mathrm{TM}} \mathrm{XLG}$ ) were added into the incubators which are overcome by a OxiTop® (WTW) respirometer. DOC was also analysed with type Shimadzu TOC5000A. Control samples, consisting in a substrate of glucose solution of 23 and $46 \mathrm{mg} \mathrm{l}^{-1}$, coinciding to a theoretical BOD of 17 and $34 \mathrm{mg}$, have ensured the reliability of the experiments (Rodier, 1996).

Bedrock (T4), soil (LA3-OL; LA3-A1) and riverine (SL-LA12) samples were considered as substrates for biodegradation assays. Incubation of these samples were stopped after 12, 23 and 56 days and judged to be complete when no further increase in cumulative oxygen 
uptake was noticed over a $24 \mathrm{~h}$ period. For each steps, biodegradation residues were filtrated and then subjected to RE6 pyrolysis. Shape of $S_{2}$ curves was compared with that of the initial samples, (Figure 5). Because there is indubitably a contamination of filter and bacteria mixing with the samples during their rescue after each BOD stages, we have pyrolysed a mixture comprising filter and bacteria. This blank sample (filter and bacteria), were also pyrolysed in order to control their contribution to the analysed samples $\mathrm{S}_{2}$ signal.

\author{
RESULTS \\ ROCK-EVAL 6 PYROLYSIS
}

\title{
Bedrocks
}

Callovo-oxfordien (T4) and Upper Aalenian shales (BR6R2) shales exhibit the highest TOC values $(0.5<\mathrm{COT}<0.7 \%$ ) (Figure 6a). Lower Aalenian carbonates (BR4R) and Bajocian marly limestones (BR2R) show rather modest values of TOC comprised between 0.10 to $0.15 \%$. These low TOC are also accompanied by low HI between 26 and $100 \mathrm{mg}$ HC.g ${ }^{1}$ TOC (Figure 6b).

\section{Alterites}

TOC of samples from A-LA1 profiles, underlain by black shales, roughly decrease from the subsurface (1.87\%, A-LA1-1) to a depth of $35 \mathrm{~cm}$ (A-LA1-6, 0.26\%) and then values slightly decrease (Figure 6c). If one exclude, the deeper samples A-LA1-6 and 10 (188 and $126 \mathrm{mg}$ HC. $\mathrm{g}^{-1}$ TOC), HI values tend to markedly decrease with depth from 178 down to $59 \mathrm{mg}$ HC. $\mathrm{g}^{-}$ ${ }^{1}$ TOC (Figure 6c)

\section{Soil profiles}

Whatever the considered catchment, soils samples exhibit similar trends of their TOC values (Figure 6d). Litter horizons (OL and OF) show more often values between 30 to $40 \%$, excepted for BR10 profile, for which the higher TOC values is only of $11.91 \%$. TOC values decrease from $\mathrm{OH}$ horizons (5 to $30 \%)$ to the organo-mineral horizon $\mathrm{A} 1(1.82-3.84 \%)$. Evolution of $\mathrm{IH}$ values along soil profiles (Figure 6e) follows also the same trend than TOC values. Litter horizons (OL and OF) exhibit high HI values (340-533 $\left.\mathrm{mg} \mathrm{HC} . \mathrm{g}^{-1} \mathrm{TOC}\right)$. HI decreases from $\mathrm{OH}$ horizons $\left(320 \mathrm{mg} \mathrm{HC} \mathrm{g}{ }^{-1} \mathrm{TOC}\right)$ to horizons $\mathrm{Al}\left(157-226 \mathrm{mg} \mathrm{HC} \cdot \mathrm{g}^{-}\right.$ ${ }^{1}$ TOC).

\section{Riverine particles}

Rock-Eval parameters differ slightly following the watersheds (Figure 6a,b). The single suspended load collected in the Le Brusquet watershed shows modest TOC $(1.26 \%)$ and HI (121 mg HC . ${ }^{-1}$ TOC) while bed load sample is characterised by lower TOC $(0.72 \%)$ and HI values (28 mg HC. $\mathrm{g}^{-1} \mathrm{TOC}$ ). Conversely, geochemical parameters from SL and BL samples originate from Le Laval are rather lower. Whatever the date of sampling, SL samples provide TOC values comprised between 0.5 and $0.65 \%$ and $\mathrm{HI}$ values from 50 to $75 \mathrm{mgHC} \mathrm{g}^{-1} \mathrm{TOC}$. The two BL samples are characterised by TOC identical to those of SL sample but with lower HI values (near $30 \mathrm{mgHC} \mathrm{g}^{-1} \mathrm{TOC}$ ).

\section{Global Geochemical data}


RE6 pyrolysis results are also illustrated in the Figure 7 describing the evolution of $\mathrm{HI}$ and $1 /$ TOC for the whole studied samples. This enables a comparison between geochemical signatures of OM from each pool.

Litter samples provide high HI and TOC values steadily decreasing down to Al horizon samples, and for the latter, their geochemical signature provide an intermediate response between litter and bedrock samples. This trend can reflect either a progressive alteration of recent $\mathrm{OM}$ (mineralisation of $\mathrm{OC}$ ), due to bacterial activity and weathering caused by water infiltration, or a mixture between recent and fossil OM. These two assumptions could also conjointly act.

The absence of litter horizons coupled with the concomitant act of these two previous hypotheses would explain why the most surficial sample ALA1-1 exhibits the same geochemical signature than samples A1 in the same catchment. From ALA2 to ALA5, the two geochemical trends are consistent both with a pursuit of the mineralisation and with an increase of a fossil contribution to the mixture of OM. However, if the deep part of the profile (since ALA1-6) is characterised by 1/TOC higher than underlain marls and claiming for a mineralisation of $\mathrm{OC}$, interpretation of $\mathrm{HI}$ values trend in the deep part of alterite is rather unclear (see Figure 6c). Excepted ALA-6 and 10, these values are quite similar to that of bedrock (T4 sample, Figure 6a,b). So, from ALA-6 to 10, if we consider that OM has essentially a fossil origin, these results may indicate a FOC mineralisation without qualitative changes in FOM.

Geological samples provide poor HI, lower than $100 \mathrm{mg} \mathrm{HC} \mathrm{g}^{-1} \mathrm{TOC}$ (Figure $6 \mathrm{~b}$ ) and a higher 1/TOC ratio than 1.43 (Figure 7). Although their TOC values are consistent with those previously recorded for same lithology but for Lower Cretaceous rocks of the Vocontian Basin (SE France, Bréheret and Herbin, 1987), their very low HI values would be the upshot of weathering process of outcropping bedrocks.

At first glance, according to the considered catchment, a close correlation between geochemical data of riverine particles and bedrocks samples is observed. For Le Laval watershed, SL and BL samples exhibit an equivalent 1/TOC ratio to those of CallovoOxfordian marly sample (T4). However, SL sample from Le Brusquet is characterised by lower 1 /TOC ratio than the outcropping substratum. SL geochemical fingerprint would be interpreted in term of mixture between fossil and recent OM inherited from soils and vegetal cover. One of the relevant argument supporting this statement is the higher density of the vegetal cover in Le Brusquet (87\% of the catchment) compared with that of le Laval $(21.7 \%)$. These observations clearly evidence the input of FOC in supergene environment by the discharge of fossil OM in river. In addition TOC values of riverine particles are consistent with those exhibited by marly bedrocks and not those of limestones, and thereby, would argue for a preferential delivery of FOC in rivers by marly facies (Figure 6a). However and excepted for sample SL-LA9, HI data from stream particles are slightly lower than the bedrocks one - low HI being more pronounced for BL samples (Figure 6b; Figure 7). This lower amount of hydrocarbon compounds contained in OM framework from BL samples would indicate a gentle oxidation of FOM which preferentially affects hydrocarbon compounds and thus induces a decrease in HI values (Lo and Cardott, 1995).

\section{$\mathrm{S}_{2}$ SIGNAL DECONVOLUTION}

Relative contribution of clusters (F1, F2, F3, F4, F5 and F6), for which their Tpeak were defined in Methods section, varies according the samples and the location where they have been collected (Figures 3-4). 


\section{Bedrocks}

The 6 clusters have been well characterised in all bedrock samples but except for F6, without significant trends and with a large variation of their contribution (Table. 3, Figure 3).

\section{Alterites}

$\mathrm{S}_{2}$ signals from alterite samples were also subjected to a deconvolution (Table 3). These samples were mainly characterised by the 4 following clusters (F1, F3, F4, F5 and F6). Evidence of the F1 cluster occurs bellow $25 \mathrm{~cm}$ depth, furthermore, the deeper is the collected sample, the more expressed is the F1 contribution, which rise up to 50\%. Except for the surface sample ALA1-1, no contribution of F2 is registered. No vertical trend has been recorded for F3 cluster, which represents however a large part of $S_{2}$ signals (20 to $44.5 \%$ ). Although significantly preponderant in the first $20 \mathrm{~cm}$, with a contribution from 17 to $48 \%$ for samples ALA1-1 and ALA1-4 respectively, F4 contribution roughly decreases and becomes relatively minor (0-12\%) for the deeper samples. Evidences of a contribution of the most thermally stable clusters, F5 and F6, is recorded without clear trends with depth.

\section{Soils}

Contrary to bedrock, only five clusters appear in soil samples (F2, F3, F4, F5 and F6). (Figure 4, Table 3). F2 and F3 contributions decrease from litter horizons (respectively near $37 \%-35 \%$ ) to horizon A1 (down to 15\% - 25\%). F4 and F5 increase from litter (an average of $14 \%$ - $18 \%$ respectively) to horizon A1 (up to $24 \%-21 \%$ ). The most thermally stable cluster F6 is never observed in litter and exhibits a modest contribution from 2 to $17 \%$ in horizon A1.

\section{Riverine}

As previously seen with Rock-Eval data, clusters distribution in SL samples varies following the watersheds (Figure 3; Table 3). F4 is defined as the major cluster after deconvolution in Le Brusquet. F2 and F5 present relative a contribution of $10 \%$ and $20 \%, \mathrm{~F} 1, \mathrm{~F} 3$ and F6 are minor or even absent, their relative contributions do not exceeding 3\%. For SL samples from Le Laval, F1, F3 and F6 are well-evidenced (average of about 22, 38, 21\% respectively). With 4 and $9 \%$ respectively, F2 and F5 exhibit a poor relative contribution in these suspended loads, and excepted for SL-LA9 (21\%), F4 is absent.

This discrepancy between clusters distribution of the two catchments is also observed for $\mathrm{BL}$ samples. For the unique BL sample from Le Brusquet, contribution of F1 (15.5\%) is higher than of the SL sample (1.5\%). F4 and F5 have a prevalent contribution (85\%) and F2, F3 and F6 are rather inconspicuous. In Le Laval, F2 is nonexistent; F6, F1 and F3 are major whereas F4 and F5 represent a modest part of $\mathrm{S}_{2}$ signals (about $10 \%$ in average).

\section{BIOCHEMICAL OXYGEN DEMAND}

Analysed samples exhibit a significant but variable increase in BOD values according time (Figure 8). Litter sample LA3-OL is characterised by a progressive increase in BOD value up to the term of the biodegradation experiment and presents a high final BOD $\left(>40 \mathrm{mgO}_{2} \mathrm{l}^{-1}\right)$. This result contrasts with those obtained for other samples (SL-LA12; LA3-A1 and T4) characterised by an increase from low BOD values $\left(<10 \mathrm{mg} \mathrm{d}^{\prime} \mathrm{O} 2 \mathrm{l}^{-1}\right)$ only during the first 12 days and further, a stabilisation of this signal (Figure 8). 
OC biochemically weathered can be calculated by the following relation (expressed in $\mathrm{mg}$ ):

$$
\mathrm{OC}_{\text {degraded }}=\mathrm{TOC}_{\text {initial }}-\left(\mathrm{TOC}_{\text {remain }}+\mathrm{DOC}\right)
$$

Conjointly to BOD record, the amount of altered OC from litter sample increases up to the end of experimental incubation duration. For other samples, their values are invariant after 12 days (Table 4). After 56 days, the yield of OC consumed from litter, A1 horizon, SL and marly bedrock is $78,50,44$ and $35 \%$ respectively.

\section{S2 signals evolution during BOD tests}

Soil samples from OL and Al horizons mainly contain organic component that are pyrolysable at temperature between 300 and $480^{\circ} \mathrm{C}$ (Figure 5). More particularly for the litter sample, the longer is the duration of the BOD test, the more significant is the emergence of a shoulder at $480^{\circ} \mathrm{C}$. This temperature corresponds to $\mathrm{F} 5$ cluster and occurs to the detriment of that characterising $\mathrm{F} 3$ cluster $\left(380^{\circ} \mathrm{C}\right)$.

For marly sample, hydrocarbon released during the beginning of pyrolysis ( $\mathrm{F} 1$ cluster) incurs an abrupt decrease caused by bacterial attack (Figure 5). The last step of experiment is also characterised by a decrease of $\mathrm{F} 4$ cluster $\left(435^{\circ} \mathrm{C}\right)$ to the benefit of the most refractory cluster $\mathrm{F} 6\left(550^{\circ} \mathrm{C}\right)$.

Although the discrepancy with the initial $\mathrm{S}_{2}$ signal of bedrock sample, $\mathrm{S}_{2}$ pyrograms of $\mathrm{SL}$ samples during BOD tests exhibit a similar fingerprint to that of geological sample (Figure $5)$.

Hydrocarbon release upon pyrolysis of the blank sample (filter and bacteria) is occurred following a temperature range of 250 to $450^{\circ} \mathrm{C}$. This temperature range is typical of these including F1, F2, F3 and F4 clusters (Figure 9). So, it is expected that filter and bacteria participate to the observed contribution of these 4 clusters to the $S_{2}$ signal of all samples subjected to BOD tests. However, these results not counteract those obtained with the bedrock sample and exhibiting, during the BOD tests, a progressive disappearance of some clusters having a low thermal stability (F1 to F4) to the benefit of that having a strong one (F6).

\section{DISCUSSION}

Global geochemical data show significant FOC input in streams without any degradation of these carbonaceous particles. Conversely, FOC delivered in soils, through alterite, strongly depends on (bio)chemical weathering processes. More accurately, we postulate that chemical processes (i.e. oxidation and hydrolysis) reigns in the deep horizon of alterite, and a coupling between bacterial activities and these processes rather acts in the upper part of this transitional reservoir and along soil profiles.

\section{Definition of fossil geochemical markers}

A key requirement for defining the occurrence and fate of FOC in supergene carbon pool is to identify a fossil fingerprint in OM mixture of a considered pool. In this study, we would propose Rock-Eval 6 pyrolysis and more especially $S_{2}$ signal deconvolution as a tool to 
define such fingerprint. For litter samples of the two watersheds, deconvolutions of $\mathrm{S}_{2}$ signals deliver exclusively clusters F2 to F5 without any occurrence of F1 and scarcely F6 (Figure 4; Table 3). At first sight and as testified with BOD experiments, their biodegradation products are also provided only these 4 clusters, which constitute the main components of the deconvolution of $\mathrm{S}_{2}$ signals after BOD (Figure 5). On the contrary, F1 and F6 as well as the other clusters F2 to F5, are often observed after the deconvolution of $\mathrm{S}_{2}$ signal from bedrocks samples and riverine particles (Figure 3 ).

Henceforth, F1 and F6 being exclusively reported in the bedrock formation and riverine particles, these two extreme clusters will be here considered as geochemical markers of FOM. Furthermore and according to BOD tests, F1 appears to be very sensitive to bacterial attack while F6 appears more recalcitrant to this biodegradation.

\section{Fate of geochemical fossil markers in the different supergene carbon pools}

The role of gully erosion and (bio)chemical weathering to the fate of FOC in supergene environment can be surveyed by tracking the fossil markers (F1 and F6) in and between these various supergene reservoirs

Figure 10 deciphers the evolution of these two markers throughout the soil profiles. As previously stated, F1 and F6 do not exist in litter horizons whereas F6 is observed in organomineral horizons (Table 3). The process of FOC delivery in soil would merely favours the preservation of the most recalcitrant hydrocarbon cluster F6. Because of its labile characters through (bio)chemical weathering, F1 is entirely mineralised since the deep soil horizon. Undoubtedly, mineralisation of cluster F1 occurs either when FOM is incorporated in soil pool, where bacterial activity is supposed predominant, or when FOM resides in alterite, a transitional compartment between bedrock and soil. So examination of the fate of F1 (and F6) in ALA1 profile can provide reliable indications for the beginning of its mineralisation.

At the bottom of ALA1 profile, contribution of both F1 and F6 to the $S_{2}$ signal is about $55 \%$ (Figure 11; Table 3), but however, exhibits different trends toward the top of the profile. If F6 shows a homogeneous contribution through the profile (about 10-15\%), F1, dominant in deep $(40 \%)$ drastically decreases when the transition alterite / soil arises.

The occurrence of F6 in this alterite profile reinforces our previous assumption about the strong recalcitrant power of $\mathrm{F} 6$ through weathering and bacterial attacks. A contrario, $\mathrm{F} 1$ is mineralised when fossil organic particles are reincorporated into soils and even into the upper part of alterite, where (bio)chemical weathering is effective.

Although their contribution varies according to the catchments, F1 and F6 clusters were often recognised after the deconvolution of $\mathrm{S}_{2}$ signal of $\mathrm{SL}$ and above all of those of $\mathrm{BL}$ particles (Table 3). On the scale of these catchments, occurrence of these fossil clusters, more strongly expressed in particles inherited from Le Laval, would mean that FOC delivery in rivers occurs following the preservation of the most labile cluster F1 as well as the most recalcitrant cluster F6, without significant changes in the geochemistry of FOM (Figure 6a, b, Figure 12).

\section{Relationship between supergene processes and FOC release in supergene carbon cycle}

By the fate of the geochemical markers identified in this study, a general sketch describes the movement of FOM in modern environments following the major supergene processes (erosion and weathering) acting in and between the different reservoirs (Figure 12). In the Draix catchments, mechanical erosion corresponds to gully erosion of marls engendering badlands 
facies. This erosion is supposed to be the main process reloading FOC in streams (DiGiovanni et al., 1999b). Chemical weathering leads to the formation of alterite profiles (Campy and Macaire, 2003). (Bio)chemical weathering occurs, and must be also considered, when alterites are overlaid of vegetation propitious for soil development and consequently for bacterial activity (Figure 12).

As seen with their similar TOC values (Figure 6a), geochemical fingerprints of riverine particles and bedrock samples are very close. So, bedrock to river fluxes, ruled by gully erosion, are characterised by the qualitative and quantitative preservation of FOM and are effective without any significant FOC mineralisation (Figure 12). Absence of mineralisation of fossil materials from the catchment is also argued by the occurrence of pyrite, optically observed in stream particles (Copard et al., in correction), and characterised by weathering rate higher than that of OC (Littke et al., 1991).

Bedrock to alterite fluxes, ruled by chemical weathering, are characterised by the pyrite disappearance, probably oxidised into sulphate (Copard et al., in correction). Because TOC values of the deep samples from alterite are lower than the bedrock one, a significant mineralisation of FOC is also reported. However, these deep samples exhibit similar qualitative feature (HI parameter and deconvolution) than those of the underlain bedrocks (Figure 6c). This would mean that FOM nature remains unchanged in deeper parts of alterite (Figure 12).

Alterite to soils fluxes, dominated by (bio)chemical weathering are characterised by a strong mineralisation of FOC as well as qualitative changes of FOM (Figure 12). Indeed, if the geochemical and recalcitrant cluster F6 remains unaltered, F1, widely more labile, is eradicated both in the upper part of alterite profile and in soil. Because soil OM content is a mixture between recent and ancient $\mathrm{OM}$, as testified by TOC and $\mathrm{HI}$ values of upper samples higher than the bedrock, the effective FOC mineralisation evidenced by F1 disappearance has not been yet quantified.

These results show that various supergene processes (erosion and (bio)chemical weathering) leading to FOC delivery in the supergene carbon cycle exert a decisive influence on the fate of this FOC, and notably its preservation and / or its mineralisation, in such modern environments (Figure 12).

\section{CONCLUSIONS}

Impact of erosional and (bio)chemical weathering processes on the delivery and fate of FOM in the supergene carbon cycle was supported by a geochemical approach: Rock-Eval 6 pyrolysis. $\mathrm{S}_{2}$ signal deconvolutions have significantly contributed to identify hydrocarbon clusters, which some of them were defined as fossil geochemical markers. These markers were then tracked through the different supergene carbon pools and their possible incurred changes due to alterations occurring in these environments were also examined.

Results show that erosional and weathering processes have a strong influence on the release and fate of FOC in supergene carbon cycle:

Between bedrocks to alterite pools, input of FOC, ruled by chemical weathering, experiences a significant mineralisation without significant qualitative changes.

Between alterite and soil, input of FOC, ruled by a predominant (bio)chemical weathering, experiences a significant qualitative and quantitative changes.

Between bedrock and riverine, input of FOC, ruled by mechanical (gully) erosion, experiences any changes, both qualitative than quantitative. 
Our results also suggest that FOC reload in supergene cycle can act either as a sink or a source of carbon for the global carbon cycle (Figure 12). Indeed, at this catchments scale, FOC delivery to streams due to gully erosion, is achieved without mineralisation and consequently without $\mathrm{CO}_{2}$ contribution to the atmosphere. $\mathrm{FOM}$ may act as the maintaining of an ancient carbon sink which was effective during the photosynthesis process of the FOM precursor. But a damper should be made: the fate of FOM in river is obviously regulated by biological activity and hydrolysis in this pool. Conversely, FOM delivered in alterites and in soils is ruled by (bio)chemical weathering. Such release is marked by FOC mineralisation and consequently promotes a possible release of $\mathrm{CO}_{2}$ in atmosphere. In this case, FOM can act as a carbon source for atmosphere. This role as source or sink for the supergene carbon cycle may be evaluated by a ratio established between the mineralised vs. the preserved parts of FOC (i.e. labile vs. recalcitrant compounds) residing on continental surfaces. This ratio depends both on supergene processes than chemical and structural features of FOM.

Up to now, for supergene processes, we can hypothesise that the fate of FOC is mainly governed by the mechanical media (erosion), that is 4 to 11 times higher than chemical (weathering) one (Probst, 1992; Gaillardet, pers. com.). However, because it depends on climate and tectonic, it is obvious that mechanical/chemical ratio did not stop varying through geological times, as it has been previously stated for Holocene period (Macaire et al., 1997 ; Di-Giovanni et al., 1999c ; Bichet et al., 1999). In addition, the time, and notably the duration for which a FOM is subjected to (bio)chemical weathering should be considered. This parameter, governing FOM turnover in supergene carbon pools and notably in soils, acts as a positive feedback onto the mineralisation extent of FOC.

For parameters peculiar to $\mathrm{OM}$, the observed and contrasted behaviour of geochemical markers through alteration suggests that the more important is the labile fraction, the faster is the mineralisation in supergene environment. Labile or recalcitrant nature of FOM through biochemical weathering is a function of chemical composition, structural organisation degree (e.g. crystallinity and micro-porosity) of FOM. These two parameters depend on the maturity level of FOM which vary according the geological setting and history of a sedimentary basin. This non-exhaustive list of parameters highlights the complexity to assess such a mineralised / preserved FOC ratios, though essential to the knowledge of FOC fate in the global carbon cycle. For the global carbon cycle, such quantification appears to be primordial to circumvent the lack of FOC stocks and fluxes in modern environments.

\section{ACKNOWLEDGEMENTS}

This work is a contribution of the GIS "Bassins de Draix, étude de l'érosion en montagne" driven by the CEMAGREF and was financially supported by the CNRS program INSU PNSE-ACI 2001: Influence de l'érosion sur les flux de matière organique fossile dans les géosystèmes continentaux actuels (sols, cours d'eau) : bassins expérimentaux de Draix, Alpes de Haute Provence, France. Authors warmly thank Nicolle Mathys (CEMAGREF, ETNA, Grenoble) and Marie Bonnard (ENSAR) for their valuable assistance. Analytical and technical supports were performed by Marielle Hatton and Didier Keravis

\section{REFERENCES}

Adams J, Faure H. 1996. Changes in moisture balance between glacial and interglacial conditions: influence on carbon cycle processes. In Global continental change: The 
context of palaeohydrology, Brandson J, Brown AG, Gregory KJ (eds). Geological Society Special Publication; 115: 27-42.

Aitkenhead JA, McDowell WH. 2000. Soil C:N ratio as a predictor of annual riverine DOC fluxes at local and global scales. Global Biogeochemical Cycles 14: 127-138.

Albéric P. 1998. Transformation of riverine organic matter from sinking stream recharge to spring discharge in a karst aquifer. Mineralogical magazine 62a: 36-37.

Amiotte-Suchet $\mathrm{Ph}$. 1995. Cycle du carbone, érosion chimique des continents et transferts vers les océans. Mémoire des Sciences Géologiques 97, University of Strasbourg; 100p

Amiotte-Suchet Ph, Probst JL, Ludwig W. 2003. Worldwide distribution of continental rock lithology: implications for the atmospheric/soil $\mathrm{CO} 2$ uptake by continental weathering and alkalinity river transport to the oceans. Global Biogeochemical Cycles 17(2): 1038, doi: 10.1029/2002GB0011891

Balesdent J. 1996. The significance of organic separates to carbon dynamics and its modelling in some cultivated soils. European Journal of Soil Science 47: 485-493.

Batjes NH. 1996. Total carbon and nitrogen in the soils of the world. European Journal of Soil Science 47: 141-163.

Berner RA, Lasaga AC, Garrels RM. 1983. The carbonate-silicate geochemical cycle and its effects on atmospheric carbon dioxide over the past 100 millions years. American Journal of Science 283: 641-683.

Bichet V, Campy M, Buoncristiani JF. 1999. Variations in Sediment Yield from the Upper Doubs River Carbonate Watershed (Jura, France) since the Late-Glacial Period. Quaternary Research 51: 267-279.

Bilodeau G, de Vernal A, Hillaire Marcel C, Josenhans H. 1990. Post glacial palaeoceanography of Hudson bay: stratigraphic microfaunal and palynological evidence. Canadian Journal of Earth Sciences 27: 946-963.

Blair NE, Leithold EL, Ford ST, Peeler KA, Holmes JC, Perkey DW 2003. The persistence of memory: the fate of ancient sedimentary organic carbon in a modern sedimentary system. Geochimica et Cosmochimica Acta 61(1): 63-73.

Bréhéret JG, Herbin JP. 1987. Matière organique : validité des données d'affleurement montrée sur un exemple crétacé moyen dans le bassin vocontien (SE de la France); corrélations entre les données de surface et de forage. Comptes Rendus de l'Académie des Sciences 305(II): 199-202.

Brochot S, Meunier M. 1995. Erosion de badlands dans les Alpes du sud, Synthèse. In Compte-rendu de recherches $n^{\circ} 3$ BVRE de Draix, Cemagref: Antony

Campy M, Macaire JJ. 2003. Géologie de la surface; Erosion, transfert et stockage dans les environnements continentaux, $2^{\text {nde }}$ edition, Dunod Publishers: Paris

Carter MR, Angers DA, Gregorich EG, Bolinder MA. 1997. Organic carbon storage and nitrogen stocks and storage profiles in cool, humid soils of eastern Canada. Canadian Journal of Soil Science 77(2): 205-210.

Combaz MA. 1980. Les kérogènes vus au microscope. In Kerogen. Insoluble matter from Sedimentary Rocks, Durand B (eds). Technip: Paris; 56-112

Copard Y. 2002. Altération diagénétique et post-diagénétique (thermicité et oxydation) des charbons carbonifères du Massif Central français (Saint-Etienne, Graissessac et autres lieux). doctoral thesis, University of Orléans; 305p. http://tel.ccsd.cnrs.fr/documents/archives0/00/00/19/02/index_fr.html

Copard Y, Di-Giovanni Ch, Martaud T. What happens to fossil organic matter in superficial carbon pool ?: optical investigations. in correction for Terra Nova.

Degens ET, Kempe S, Richey JE. 1991. Biogeochemistry of major world rivers. In Biogeochemistry of major world rivers, Degens ET, Kempe S, Richey JE (eds). SCOPE $42 ; 323-344$ 
Di-Giovanni Ch, Disnar JR, Bichet V, Campy M, Guillet B. 1998. Geochemical characterization of soil organic matter and variability of a postglacial detrital organic supply (Chaillexon lake, France). Earth Surface Processes and Landforms 23: 1057-1069.

Di-Giovanni Ch, Disnar JR, Campy M, Macaire JJ. 1999a. Variability of the ancient organic supply in modern humus. Analusis, 27(5): 398-402.

Di-Giovanni Ch, Disnar JR, Turpin S, Bréheret JG. 1999b. Estimation de la contribution des matières organiques remaniées au stock organique des sols et sédiments lacustres (bassin lacustre des Peyssiers, Hautes-Alpes, France). Bulletin de la Société Géologique de France 170(2): 121-129.

Di-Giovanni Ch, Campy M, Disnar JR. 1999c. Des particules charbonneuses, témoins des variations de l'érosion chimique d'un bassin versant calcaire durant 1'Holocène (bassin de Chaillexon, Doubs, France). Comptes Rendus de l'Académie des Sciences 328: 167-172.

Di-Giovanni Ch, Disnar JR, Macaire JJ. 2002. Estimation of the annual yield of organic carbon released from carbonates and shales by chemical weathering. Global and Planetary Change 32: 195-210.

Disnar JR, Guillet B, Keravis D, Di-Giovanni Ch, Sebag D. 2003. Soil organic matter (SOM) characterization by Rock-Eval pyrolysis: scope and limitations. Organic Geochemistry 34: 327-343.

Duchauffour P. 2001. Introduction à la science $d u$ sol; Sol, végétation, environnement. $6^{\text {th }}$ édition de l'abrégé de pédologie, Dunod Publishers: Paris

Espitalié J, Deroo G, Marquis F 1985. La pyrolyse Rock-Eval et ses applications. Revue de l'Institut Français du Pétrole 40(5): 563-579, 40(6): 755-784, 41(1): 73-89.

Eswaran H, Van Den Berg E, Reich P. 1993. Organic carbon in soils of the world. Soil Science Society of America Journal 57: 192-194.

Gadel F, Ragot JP. 1973. Sur l'allochtonie de la fraction organique particulaire des dépôts quaternaires récents du Golfe du Lion. In Advances in Organic Geochemistry 21, Tissot B, Bienner F (eds). Technips: Paris; 619-628.

Haccard J, Beaudoin B, Gigot P, Jorda M. 1989. Notice et carte géologique de La Javie au 1/50 000. BRGM Publishers: Orléans

Heddle JF, Tavener A. 1981. Evaluation of the total carbonaceous biochemical oxygen demand method, using a compensated recording respirometer. Applied and Environmental Microbiology 41: 580-584.

Hedges JI, Keil RG, Benner, R. 1997. What happens to terrestrial organic matter in the ocean? Organic Geochemistry 27: 195-212

Hikuma M, Yasuda T. 1988. Microbial sensors for estimation of biochemical oxygen demand and determination of glutamate. Methods in Enzymology 137: 124-131.

Holland HD. 1978. The chemistry of atmosphere and oceans. Wiley Interscience Publishers: Chichester, New York

Houghton RA. 2003. The contemporary carbon cycle. In treatise on Geochemistry, 8: 472513.

Johnson HA, Thomas BW. 1884. Report of the committee on the microscopic organisms in the boulder clays of Chicago and vinicity. Chicago Academic Science Bulletin 1: 35-40.

Kaufmann RK, Stock JH. 2003. Testing hypotheses about mechanisms for the unknow carbon sink: a time series analysis. Global Biogeochemical Cycles, 17(2): 1072, doi: 10. 1029/2002GB001962.

Lafargue E, Marquis F, Pillot D. 1998. Rock-Eval 6 applications in hydrocarbon exploration, production and soil contamination studies. Revue de l'Institut français du Pétrole 53(4): 421-437. 
Lin RG. 1988. Etude du potentiel de dégradation de la matière organique particulaire au passage eau douce - eau salée : cas de l'estuaire de la Gironde. doctoral thesis, University of Bordeaux I; 209p.

Littke R, Klussmann U, Krooss B, Leythaeuser D. 1991. Quantification of loss of calcite, pyrite, and organic matter due to weathering of Toarcian black shales and effects on kerogen and bitumen characteristics. Geochimica et Cosmochimica Acta, 55(11): 33693378

Lo HB, Cardott BJ 1995. Detection of natural weathering of upper Mcalester and Woodford shale, Oklahoma, USA. Organic Geochemistry 22(1): 73-83.

Ludwig W, Probst JL, Kempe S. 1996. Preidicting the oceanic input of organic carbon by continental erosion. Global Biogeochemical Cycles 10(1): 23-41.

Ludwig W, Amiotte-Suchet Ph, Munhoven G, Probst JL. 1998. Atmospheric $\mathrm{CO}_{2}$ consumption by continental erosion: present-day controls and implications for the last glacial maximum. Global and Planetary Changes 16-17; 107-120.

Macaire JJ, Bossuet G, Choquier A, Cocirta C, De Luca P, Dupis A, Gay I, Mathey E, Guenet P. 1997. Sediment yield during late glacial and Holocene periods in the lac Chambon watershed, Massif Central, France. Comptes Rendus de l'Académie des Sciences 22: 473-489.

Meybeck M. 1987. Global chemical weathering of surficial rocks estimated from river dissolved loads. American Journal of Science 287: 401-428

Meybeck M. 1993. C, N, P, and S in rivers: from sources to global inputs. In Interaction of C, $N, P$, and S, Biogeochemical Cycles on Global Change, Wollast R, McKenzie FT, Chou L (eds)., Springer Verlag: New York:163-193

Nelson PN, Baldock JA, Oades, JM. 1993. Concentration and composition of dissolved organic carbon in streams in relation to catchment soil properties. Biogeochemistry 19: 27-50.

Noël H. 2001. Caractérisation et calibration des flux organiques sédimentaires dérivant du bassin versant et de la production aquatique (Annecy, le Petit Lac) - Rôles respectifs de l'Homme et du Climat sur l'évolution des flux organiques au cours des 6000 dernières années. doctoral thesis, University of Orléans; $273 p$

Petsch ST, Berner RA, Eglinton TI. 2000. A field study of the chemical weathering of ancient sedimentary organic matter. Organic Geochemistry 31: 475-487.

Prentice IC, Farquhar GD, Fasham MJR, Goulden ML, Heimann M, Jaramillo VJ, Kheshgi HS, Le Quéré C, Scholes RJ, Wallace DWR. 2001. The carbon cycle and atmospheric carbon dioxide. In Climate change 2001: The scientific basis. Contribution of a working group I to the 3rd assessment report of the Intergouvernmental Panel on Cimate Change, Houghton JT, Ding Y, Griggs DJ, Noguer M, van der Linden PJ, Dai X, Maskell K, Johnson CA (eds), Cambridge University Press: UK and New York: 183-237.

Probst JL. 1992. Géochimie et hydrologie de l'érosion continentale, Mécanismes, bilan global actuel et fluctuations au cours des 500 derniers millions d'années. Mémoire des Sciences Géologiques 94, University of Strasbourg;161p.

Raymond PA, Bauer JE. 2001. Riverine export of aged terrestrial organic matter to the North Atlantic Ocean. Nature 409: 497-500

Richard D, Mathys N. 1997. Historique, contexte technique et scientifique des BVRE de Draix. Caractéristiques, données disponibles et principaux résultats acquis au cours de dix ans de suivi. In Les bassins versants expérimentaux de Draix, laboratoire d'étude de l'érosion de montagne, Acte de colloque oct. 97, Mathys N (eds). Cemagref: Anthony; 1128

Rodier J. 1996. L'analyse de l'eau; eaux naturelles, eaux résiduaires, eaux de mer, $8^{\text {ème }}$ édition. Dunod Publishers: Paris 